Vol. 2 | No. 4 | 2021 | Hal. 294-298

\title{
PENGADAAN SARI LEMON UNTUK PENINGKATAN KUALITAS KESEHATAN MASYARAKAT DI MASA PANDEMI COVID-19
}

\author{
Ratna Tri Hardaningtyas*, Alfi Nur Rohmaniya, Dwi Ihsani Mahendra Putra, Evi Nur \\ Fauziah, Fitri Dwi Nur Khasanah, Ragil Fananda Sofyan \\ Fakultas Ekonomi dan Bisnis, Universitas Islam Malang \\ *korespondensi email: ratnatyas@unisma.ac.id
}

\begin{abstract}
ABSTRAK
Indonesia merupakan salah satu negara di dunia yang saat ini sedang dilanda suatu wabah berupa virus yang berbahaya bagi manusia. Virus yang sedang menjadi wabah diseluruh dunia khususnya di Indonesia pertama kali ditemukan di Wuhan, China pada akhir tahun 2019. Virus tersebut dikenal dengan virus Corona (SARS-CoV-2), World Health Organization (WHO) telah mengumumkan bahwa telah terjadi suatu wabah virus Corona atau COVID-19 yang menjadikan kedaruratan kesehatan masyarakat serta meresahkan dunia (WHO, 2020). Virus ini hanya menyebabkan infeksi pernapasan ringan, seperti flu. Namun, virus ini juga bisa menyebabkan infeksi pernapasan berat, seperti infeksi paru-paru (pneumonia). Dalam rangka menjaga kesehatan tubuh, salah satu cara yang dapat digunakan dalam menjaga kesehatan guna mencegah tertularnya COVID-19 yaitu dengan dengan mengonsumsi vitain $C$ untuk meningkatkan kekebalan tubuh. Vitamin $C$ dapat dengan mudah dengan mudah ditemukan dalam buah lemon. Maka dalam program KSM-T ini dilakukan kegiatan sosialisasi terkait dengan peningkatan kualitas kesehatan dengan cara pembuatan sari lemon. Kegiatan ini dilaksanakan pada tanggal 1 Agustus 2021. Bertempat di Desa Poncokusumo Kabupaten Malang oleh mahasiswa KSM kelompok 36. Hasil dalam sosialisasi ini diketahui bahwa proses pembuatan sari lemon diawali dengan memilih jeruk lemon dengan kualitas baik, kemudian diperas untuk diambil airnya dan dilakukan perebusan untuk meningkatkan umur simpan produk yang dibuat. Sari lemon dapat bertahan pada suhu ruangan selama 7 hingga 10, sedangkan pada suhu kulkas dapat bertahan hingga 30-40 hari. Produk sari lemon ini juga memiliki tujuan jangka panjang sebagai bisnis yang berkelanjutan, hal ini dikarenakan produk pangan fungsional terus diminati oleh masyarakat untuk menjaga kesehatan tubuh.
\end{abstract}

Kata Kunci: kesehatan; imunitas tubuh; sari lemon

\section{PENDAHULUAN}

Indonesia merupakan salah satu negara di dunia yang saat ini sedang dilanda suatu wabah berupa virus yang berbahaya bagi manusia. Virus yang sedang menjadi wabah diseluruh dunia khususnya di Indonesia pertama kali ditemukan di Wuhan, China pada akhir tahun 2019 (Yuliana, 2020). Virus tersebut dikenal dengan virus Corona (SARS-CoV-2), World Health Organization (WHO) telah mengumumkan bahwa telah terjadi suatu wabah virus Corona atau COVID-19 yang menjadikan kedaruratan kesehatan masyarakat serta meresahkan dunia (WHO, 2020). COVID-19 disebabkan oleh coronavirus merupakan virus RNA yang serupa dengan virus flu burung atau avian influenza virus (AIV) dan sama-sama mempunyai sifat antigenic drift (genetic shift) (Wasito \& Wuryastuti, 2020). Pada banyak 
kasus, virus ini hanya menyebabkan infeksi pernapasan ringan, seperti flu. Namun, virus ini juga bisa menyebabkan infeksi pernapasan berat, seperti infeksi paru-paru (pneumonia). Virus ini menular melalui percikan dahak (droplet) dari saluran pernapasan, misalnya ketika berada di ruang tertutup yang ramai dengan sirkulasi udara yang kurang baik atau kontak langsung dengan droplet (Fadlika et al., 2021).

Seseorang dapat tertular COVID-19 melalui berbagai cara, yaitu: a) Tidak sengaja menghirup percikan ludah dari bersin atau batuk penderita Covid-19, b) Memegang mulut atau hidung tanpa mencuci tangan terlebih dahulu, setelah menentuh benda yang terkena cipratan air lir penderita COVID-19, c) Kontak jarak dekat dengan penderita COVID-19, misalnya bersentuhan atau berjabat tangan, d) Virus corona dapat menginfeksi siapa saja (Apriliany et al., 2021), tetapi efeknya akan lebih berbahaya atau bahkan fatal bila terjadi pada orang lanjut usia, ibu hamil, orang yang sedang sakit, atau orang yang daya tahan tubunya lemah (Ilpaj \& Nurwati, 2020).

Pada banyak kasus orang terkena COVID-19 karena daya tahan tubuh yang lemah. Berbagai cara meningkatkan imunitas tubuh agar tidak mudah sakit: a) Tidur yang cukup, b) Rutin berolahraga, c) Menghindari rokok dan minuman beralkohol, d) hindari stres, e) perbanyak makan sayur dan buah, f) minum vitamin. Bapak Presiden Joko Widodo pernah menyampaikan pidatonya bahwa bahwa kita dianjurkan untuk meminum jamu untuk menangkal virus corona. Tidak hanya itu vitmain $\mathrm{c}$ juga sangat dibutuhkan banyak orang untuk menjaga imunitas tubuh.

Lemon (Citrus limon) merupakan salah satu famili dari tanaman jeruk yang dikenal dengan nama citrun, buahnya berbentuk lonjong, bulat dengan diameter $5-7 \mathrm{~cm}$ atau lebih ada tonjolan pada ujungnya, tidak berbji kalau ada biasanya satu atau dua, warna kulit pada buah yang telah matang berwarna kuning cerah, rasanya asam, sepet, sedikit manis (Lingkarkata, 2019). Lemon lebih populer dalam industri kuliner karena memiliki aroma citrus yang segar dan bagian yang digunakan air perasan dan kulitnya. Dibalik rasanya yang asam jeruk lemon (Citrus limon) merupakan tanaman yang sangat bermanfaat bagi kesehatan maupun untuk kecantikan (Lindawati \& Nofitasari, 2021).

Lemon mempunyai berbagai vitamin, seperti vit A, B6, dan C. Jeruk lemon mengandung 3,7\% asam sitrat dan vitamin C 40-50 mg / $100 \mathrm{~g}$ (Kristanto, 2013). Selain itu lemon juga mengandung beragam nutrisi seperti kalium, kalsium, fosfor, magnesium, zinc, dan berbagai antioksidan seperti hesperidin, diosmin, dan eriocitrin. Dengan adanya berbagai vitamin dan nutrisi tersebut, membuat lemon memberikan manfaat yang cukup banyak bagi tubuh.

Pengabdian masyarakat merupakan bagian tak terpisahkan dari filosofi Tri Dharma Perguruan Tinggi yang implementasinya berbasiskan penelitian maupun pembelajaran. Oleh karena itu, pada masa pandemi COVID-19 ini hati nurani civitas akademika Universitas Islam Malang sebagai institusi yang tumbuh dan berkembang di tengah masyarakat merasa terpanggil, yaitu dengan mengadakan program pengabdian masyarakat melalui kegiatan Kandidat Sarjana Mengabdi (KSM-T).

Berdasarkan latar belakang diatas, dengan adanya program KSM-T, mahasiswa KSM kelompok 36 tertarik untuk melakukan kegiatan sosialisasi terkait dengan peningkatan kualitas kesehatan dengan cara pembuatan sari lemon.

\section{METODE}

Kegiatan ini dilaksanakan pada tanggal 1 Agustus 2021. Bertempat di Desa Poncokusumo Kabupaten Malang. Tepat pada pukul 15.00-18.00 WIB. Alat-alat yang digunakan dalam pembuatan sari lemon antara lain adalah alat peras jeruk, panci, pengaduk, filter kain, kompor, dan botol. Sedangkan bahan-bahan yang digunakan pada pembuatan sari 
lemon adalah buah lemon. Metode yang kami gunakan adalah metode sosialisasi dan pelatihan dalam pembuatan sari lemon.

\section{HASIL DAN PEMBAHASAN}

Salah satu cara untuk menjaga imunitas tubuh adalah dengan minum sari lemon. Sari lemon merupakan minuman yang mempunyai vitamin $C$ baik bagi tubuh manusia. Sari lemon juga tidak hanya memiliki kandungan vitamin $C$ namun juga ada banyak vitamin lain seperti vitamin A, vitamin B6 dan kalsium. Sari lemon juga mudah untuk dibuat karena bahan- bahannya mudah untuk dicari.

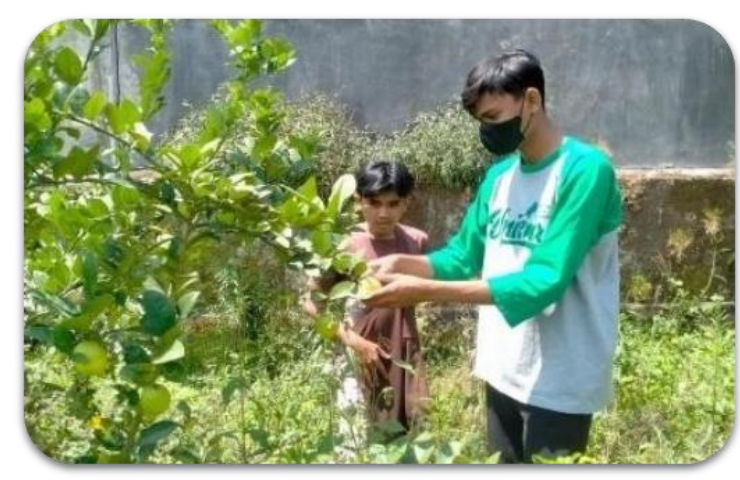

Gambar 1. Pemetikan Jeruk Lemon

Mahasiswa melakukan kegiatan sosialisasi dan pelatihan kepada warga Desa Poncokusumo, Kecamatan Poncokusumo, Kabupaten Malang, karena setelah melakukan survey, diketahui bahwa masyarakat Desa Poncokusumo mempunyai tanaman jeruk lemon yang hanya setiap panen langsung dijual, masih belum tau tata cara pengolahan sari lemon dengan baik. Dengan adanya kegiatan ini diharapkan masyarakat mampu memahami sekaligus mengingkatkan kesehatan dengan cara pengolahan sari lemon yang baik.

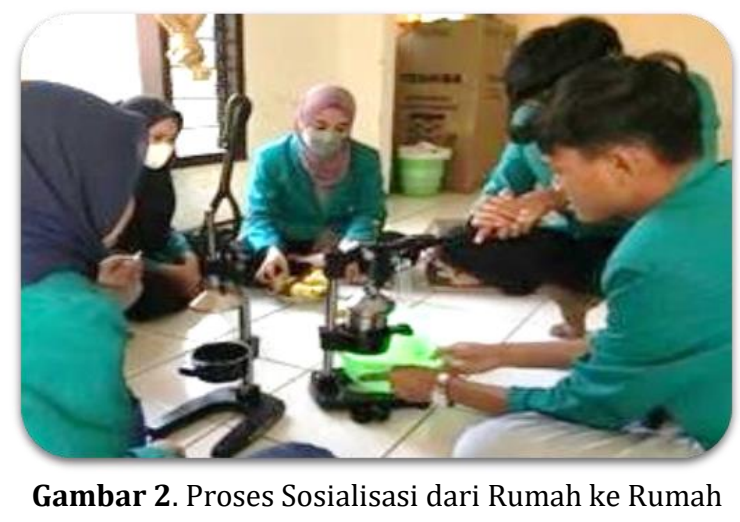

Proses pembuatan sari lemon adalah dengan memilih jeruk lemon dengan kualitas baik, kemudian diperas untuk diambil airnya. Air perasan jeruk lemon yang sudah terkumpul masih belum bisa dikonsumsi langsung namun diolah terlebih dahulu yakni melalui proses perebusan seperti memanaskan santan kelapa yang dimana tidak sampai pecah kemudian diendapkan untuk diambil sarinya. Sari lemon bukan merupakan minuman yang awet hingga berbulan-bulan, penyimpanan sari lemon di kulkas menambah masa tahan yang semula untuk disuhu ruangan sari lemon dapat bertahan 7-10 hari sedangkan dalam kulkas bisa bertahan hingga 30-40 hari. 


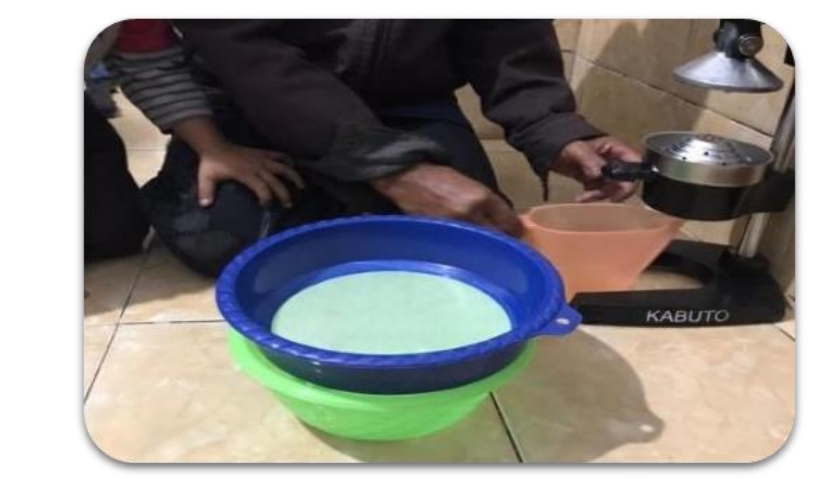

Gambar 3. Percobaan Pembuatan Sari Lemon oleh Masyarakat

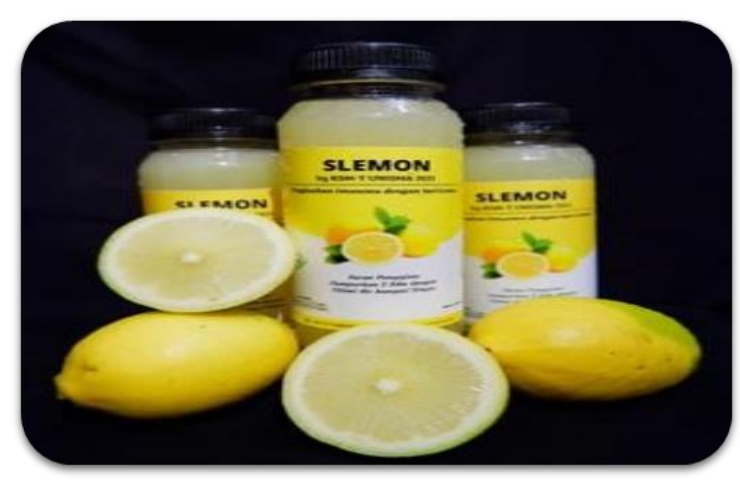

Gambar 4. Hasil Pembuatan Sari Lemon

\section{KESIMPULAN}

Sebagai salah satu desa yang ada di Kabupaten Malang pernah berada pada masa PPKM Level 4 terkait penyebaran virus covid-19, warga Desa Poncokusumo perlu melakukan pencegahan penyebaran virus ini dengan cara selalu menerapkan protokol kesehatan dan meningkatkan imunitas tubuhnya. Salah satu cara untuk meningkatkan imunitas tubuh adalah dengan mengkonsumsi vitamin yang ada disekitar kita. Maka melalui Program Kandidat Sarjana Mengabdi (KSM Tematik) Universita Islam Malang Tahun 2021 yang salah satu programnya bertujuan untuk meningkatkan imunitas tubuh manusia agar terjaga dari berbagai penyakit terutama di masa pandemi virus Covid-19.

Tujuan jangka panjangnya adalah masyarakat tidak terkena efek samping dari pengolahan buah lemon yang salah, dapat dijadikan sebagai suatu bisnis yang tetap memperhatikan kesehatan tubuh. Program Kandidat Sarjana Mengabdi (KSM Tematik) Universitas Islam Malang Tahun 2021 ini berkontribusi memberikan sosialisasi pentingnya kesehatan, cara meningkatkan imunitas tubuh dengan olahan buah lemon, kepada masyarakat Desa Poncokusumo, terutama ibu-ibu Desa Poncokusumo, Permasalahan yang dimiliki oleh salah satu peserta pelatihan adalah tidak diperbolehkan atau menghindari mengkonsumsi lemon karna memiliki riwayat penyakit maag dan bagaimana mengolah lemon agar tidak terasa pahit. Solusi yang dapat diberikan agar tidak terasa pahit adalah memastikan bahwa irisan lemon yang direndam dalam air tidak lebih dari 4 jam. Dan bagi peserta yang memiliki riwayat penyakit maag justru dengan meminum air hangat dengan perasan lemon setiap pagi yang dilakukan secara rutin, bermanfaat untuk meredakan nyeri dan mual pada lambung.

\section{DAFTAR RUJUKAN}

Apriliany, F., Umboro, R. O., Ersalena, V. F., Farmasi, P., Kesehatan, F., \& Bumigora, U. (2021). Penyuluhan Gema Cermat Obat dan Pelatihan Pembuatan Hand Sanitizer. Jurnal 
Abdidas, 2(1), 41-47. https://doi.org/10.31004/abdidas.v2i1.207

Fadlika, I., Aripriharta, Dwiwahyono, I., Andriansyah, M. R., Gunawan, M. R., Mistakim, E., \& Fakhri, A. S. (2021). Pengembangan alat sterilisasi mikroorganisme dan pelaksanaan disinfeksi berkala sebagai upaya untuk memutus rantai penularan covid-19. Jurnal Inovasi Hasil Pengabdian Masyarakat (JIPEMAS), 4(3). https://doi.org/10.33474/jipemas.v4i3.11007

Ilpaj, S. M., \& Nurwati, N. (2020). Analisis Pengaruh Tingkat Kematian Akibat Covid-19 Terhadap Kesehatan Mental Masyarakat di Indonesia. Focus : Jurnal Pekerjaan Sosial, 3(1), 16-28. https://doi.org/10.24198/focus.v3i1.28123

Kristanto, F. (2013). Kekerasan Permukaan Enamel Gigi Manusia Setelah Kontak dengan Air Perasan Citrus Limon [Universitas Airlangga]. http://repository.unair.ac.id/id/eprint/19104

Lindawati, N. Y., \& Nofitasari, J. (2021). Efektivitas Sari Buah Lemon (Citrus limon (L.) Burm. f. sebagai Khelating Agent Logam Berat Tembaga. Jurnal Farmasi Dan Ilmu Kefarmasian Indonesia, 8(1), 68-73. https://doi.org/10.20473/jfiki.v8i12021.68-73

Lingkarkata. (2019). Buku Pintar : Tumbuhan. PT Elex Media Komputindo.

Wasito, H.., \& Wuryastuti, H. (2020). Corona virus : kupas tuntas sejarah, sumber, penyebaran, patogenesis, pendekatan diagnosis dan gejala klinis coronavirus pada hewan dan manusia (D. C. F. (ed.)). Lily Publisher.

WHO. (2020). Modes of transmission of virus causing COVID-19: implications for IPC precaution recommendations.

Yuliana. (2020). Corona virus diseases (Covid-19); Sebuah tinjauan literatur. Wellness and Healthy Magazine, 2(1), 187-192. https://doi.org/10.30604/well.95212020 